\section{Shooting the messenger}

\section{The abolition of a science advisory board to the US government sends the wrong signal.}

$T$

-he Secretary of Energy Advisory Board (SEAB) is not the most charismatic or influential body to offer advice to the US federal government, and few people will even notice it has gone. Nonetheless its abolition, without any satisfactory replacement (see page 725), once again raises the spectre of the Bush administration's loathing for anything that resembles objective outside advice.

Before dispensing with SEAB's services, energy secretary Samuel Bodman said he liked to operate with fewer advisers. This was a curious statement from the standard-bearer of an energy policy that has been dogged, since early in President Bush's first term, by allegations that it was fixed during closed-door meetings between Vice-President Dick Cheney and oil-industry lobbyists.

The Bush administration has made no secret of its contempt for time-honoured Washington government practice. It was during the presidency of Richard Nixon that Congress passed several laws intended to open up the workings of government to public scrutiny. One such measure was the 1972 Federal Advisory Committee Act, which established a framework for advisory panels in which government-appointed experts would meet to discuss the issues and advise the government, in full public view.

SEAB was such a panel, made up in part of scientists and engineers. Notwithstanding the fact that the energy secretary can put who he wants on it, and the drawback that painful truths will often be kept quiet, it managed to do some good work. Last July, for example, it produced a stinging report on duplication in the energy department's nudear-weapons laboratories. The labs' powerful supporters, led by Senator Pete Domenici (Republican, New Mexico), duly did their best to bury the report. Perhaps no one will ever know whether they also played a role in Bodman's decision to bury SEAB itself.

Over the years, SEAB has managed to point out issues of waste and overlap in government laboratories that no one - department officials, Congress, contractors or staff particularly wanted to see aired.
"If Bodman disliked the direction the panel was taking, he could easily have incorporated people whose viewswere more tohisliking."

It has periodically lent public backing to the energy department's vital but unheralded role in supporting basic research in the physical sciences. Manned as it was by such luminaries as Burton Richter, the Nobel laureate and former director of the Stanford Linear Accelerator Center, and the energy economist Daniel Yergin, its output could hardly be dismissed as the work of a few renegades.

SEAB cost less than half-a-million dollars a year to run, yet it provided oversight for a department with an annual budget of more than $\$ 20$ billion. If Bodman disliked the direction the panel was taking, he could easily have incorporated people whose views were more to his liking: at least their names would be public, for all to see. The decision to abolish it instead shows contempt for the principle of transparency in government.

\section{Rightful owners}

\section{Research into anthropological artefacts must acknowledge claims of prior ownership.}

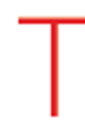

hose seeking to study archaeological specimens increasingly find the objects of their interest tied up in complex arguments over who owns them. But if museums engage openly and honestly with nations that claim ownership, they can reach compromises that will balance the potentially conflicting desires for reliable stewardship, fairness and access for both the public and researchers.

The latest episode to bring these issues to the fore concerns the stewardship of a large collection of Oceanic artefacts held by the de Young Museum in San Francisco. The collection, which includes masks, skulls and exotic carvings, could provide anthropologists with new insights into primitive peoples.

As we report on page 722 , at least nine of the 400 artefacts initially donated seem to be the national cultural property of Papua New Guinea. The items - and others among the 6,000 pieces lined up as future exhibits - came from the worldwide trade in archaeological specimens that are increasingly valued as works of art.

The de Young Museum - rebuilt at great expense after earthquake damage - started the Oceanic exhibition last October to herald its reopening. Unfortunately, given the history of dealing in such objects, no one at the museum seems to have asked questions about the provenance of the specimens when they first entered its gorgeous, copper-sheathed walls.

Yet to the museum's credit, its officials are now pledging to address the issue. A Papua New Guinea museum official has, for example, been invited to San Francisco next week to examine the artefacts. The museum's desire to work with the government of the objects' country of origin contrasts with the more haughty, colonial attitude that has sometimes characterized curators' approaches to this issue in the recent past.

The world of archaeology has been transfixed in recent months, for example, by a criminal trial in Italy of dealers and museum officials over looted artefacts that were sold on to
"Researchshould proceed on the basis of a firm and fair understanding between the museum and officials from the country of origin." the Metropolitan Museum of Art in New York and the Getty Center in Los Angeles.

The artefacts now housed in the de Young Museum are of considerable scientific interest. They offer anthropologists a window to cultures of an earlier time - possibly even to the era of the miniature hominids who lived to the west on the island of Flores a few thousand years earlier.

But such research should proceed on the basis of a firm and fair understanding between the museum that has physical custody of the objects and officials from their country of origin. All parties should work together to ensure that such an understanding is reached. 